\title{
Support for Children Who are Affected/Infected with HIVIAIDS in the Classroom
}

\author{
Maphetla M Machaba \\ Department of Early Childhood development, University of South Africa \\ P.O Box 392 Muckleuneuk 0003 \\ machabmm@unisa.ac.za
}

\section{Doi:10.5901/mjss.2014.v5n20p1766}

\begin{abstract}
Daily reports from the media on the impact of HIVIAIDS on the South African society make it clear that this disease will eventually affect every citizen in one way or another. Sontag (1997:171) puts in strong terms: "The survival of the national, of civilized society is said to be at stake". The Government Gazette (1999:4) stresses this point further by stating that HIVIAIDS is one of the major challenges to all South Africans. The Gazette quotes alarming statistics proving that this pandemic in South Africa is among the most severe in the world and it continues to increase at an estimated rate of $33.8 \%$. It is further estimated that almost $25 \%$ of the general population will be HIV positive by the year 2010. Van Dyk (2001:6) supports this statement when he says that HIVIAIDS is not a health crisis in Africa, it is a human catastrophe, which will have an impact on every living person in this region. The Joint United National Programmes on HIVIAIDS (UNAIDS, March 2001) reports that a decade ago HIVIAIDS was already regarded as a serious health crisis. It is estimated that from 1991, 9 million people in Sub-Saharan Africa were infected with HIV and that 5 million would die by the end of the decade. Furthermore, the report alleges that the actual rate of infection at the present moment is three times higher than the projection made at that time. As the 21st century dawned, 71\% (24.4 million) of all the people in the world with HIV lived in Sub-Saharan Africa. Africa's 12.1 million AIDS orphans represented $95 \%$ of the AIDS orphans in the world. Of the 5.6 million new HIV infections worldwide in 1999, 3.8 million (about 68\%) occurred in Sub-Saharan Africa - the region with the fastest growing epidemic.
\end{abstract}

Keywords: HIVIAIDS, infected children, affected children

\section{Introduction}

The South African President, Thabo Mbeki, at the launch of the Partnership Against Aids on 9 October 1998, pointed the following out: "HIVIAIDS is among us. It is real. It is spreading. We can only win against HIVIAIDS if we can join hands to save our nation. For too long we have closed our eyes as a nation, hoping the truth was not so real. For many years we have allowed HIV to spread, and at a rate in our country which is one of the fastest in the world. Every single day a further 1500 people in South Africa get infected. To date, more than 3 million people have been infected"

Van Greunen (2001:40-41) maintains that it is estimated that by 2015, the year in which HIVIAIDS is expected to reach its peak, between $9-12 \%$ of the population will be HIVIAIDS orphans. This indicates that between 3.6 and 4.8 million children under the age of 15 will be without parents or guardians.

The Education White Paper 6 (2001:34) states that the Ministry will analyse the effects of HIVIAIDS and other infectious diseases on the education system and will develop and implement appropriate and timely programmes. Although at present no special provision has officially been made for learners with HIVIAIDS, the moral obligation that educators have in teaching these learners, meeting their emotional and social needs, and understanding their physical conditions, cannot be ignored.

\section{Literature Review}

\subsection{The role of the educator with regard to unaffected learners}

Because HIVIAIDS is such a stigmatized and deadly disease, people tend to avoid and isolate infected sufferers (see par.2.3). According to Quackenbush (1997:5) it is also possible that other children will learn of the illness and harass or ostracise the child. In such a case education for schoolmates would be called for, along with strong interventions to protect the child from further negative attention. "Teachers and other adults need to find ways to give an ill or handicapped child a feeling that he is an important, useful, and valued person. He needs acceptance by others, but he 
also needs a sense of personal worth, of being valued for his unique qualities, and for what he can accomplish".

Although the media and medical personnel maintain that HIVIAIDS is not very contagious, it is unfortunately true that the risk of transmission of the HIV virus would probably be greatest in young children. "This theoretical transmission would most likely involve exposure of open skin lesions or mucous membranes to blood and possibly other body fluids of an infected person" (Schwarcz \& Rutherford, 1988:79). Parents are well aware of the fact that children are prone to hurting themselves, and it is understandable that a parent would warn his/her child to stay away from an infected friend. Although the incidence of HIVIAIDS is confidential, in a community where everybody knows each other, information spreads very fast. This knowledge about the infection leads to prejudice, discrimination and isolation.

The NCSNET/NCESS report (1997:63) affirms that educators and other professionals should be equipped through their own professional development, to prepare all educators and support providers for their role in the provision of education and support. Educators, including classroom assistants, should be equipped and accredited through various from of pre- and in-service programmes to be able to respond to diversity in the context. Educators should manage the learning programmes of the learners for which they are responsible and assess the needs of the learners collectively and individually by providing flexible programmes that accommodate a variety of needs, drawing on the resources of the learners themselves. A key role would be facilitating a learning environment that fosters respect among learners and among the learning community as a whole.

According to Morrow (1985:41): "Chronically ill children have problems feeling 'okay' about themselves and have problems with socialization. The teacher has a significant role in helping them to build self-esteem and to gain acceptance". When the other learner in the classroom sees that the teacher accepts and loves the learner with HIVIAIDS, they will also accept the child. The educator as role model and as a substitute to the parent has an important role to play in making life easier for the HIV infected learner.

According to Louw et al. (2001:19) the educator should teach learners to develop empathy and sympathy towards others and how to handle negative emotions such as anger, sadness and anxiety and when things are not going well, by encouraging them to see how their words and deeds affect others. The educator should also encourage HIV infected learners to live life fully as they can live healthy lives for many years.

The learner with HIVIAIDS is often physically weaker and smaller than his/her peers and siblings. Therefore the educator should be careful not to reinforce feelings of being different. The educator should let learners know that there are more similarities than differences between them and their peers and he/she should acknowledge that she/he knows that the learners feel different and understand why, but that it is only in a small way. He/she should also explain to them that their feelings are the same as those of other learners (Louw et al., 2001:22).

\subsection{The Role of the Educator in Supporting the Learner with Hiv/Aids}

According to the Government Gazette (1999:7): "Learners and students with HIVIAIDS should lead as full a life as possible and should not be denied the opportunity to receive an education to the maximum of their ability". Louw et al. (2001:5) supports this statement when saying that the needs of learners with HIVIAIDS with regard to their right to a basic education should as far as is reasonably possible be accommodated within the school environment. "Educators should encourage and help infected and affected learners to carry the weight of their circumstances. They will often have to be emotionally 'picked up' so that they will not fall or sink back and give up on life" (Louw et al., 2001:4)

Because HIVIAIDS is such a contagious and deadly disease, educators also fear infected learners on the one hand, and on the other hand, have negative attitudes towards these learners. As Clark and Eason (1993:35) say: "Most of us feel threatened by information and experiences that do not 'fit' with our normal way of doing (and thinking about) "things". Volberding (1988:11) links up with this argument when maintaining that educators do not need to become HIVIAIDS experts to plan and teach effectively, but they need to be familiar with this kind of information and be confident to its accuracy. A good deal of the fear surrounding HIVIAIDS stems from the feeling that there is much we do not know about the disease, it would equip them with the necessary skills and empathy to deal with infected learners.

It therefore seems that the role of the educator will have to be much wider than it has been traditionally. Apart from the usual roles associated with teachers, the following tasks should be added in the light of the incidence of HIVIAIDS in learners.

Being able to respond to current social and educational problems with particular emphasis to the issue of violence, drug abuse, poverty, child and women abuse, HIVIAIDS and environmental degradation;

Assessing and working in partnership with professional services to deal with these issues;

Counseling and/or tutoring learners who need assistance with social or learning problems;

Demonstrating caring, committed and ethical professional behavior and an understanding of education as dealing 
with the protection of learners and the development of the whole person (Government Gazette in Louw et al., 2001:6).

"The majority of infected children will show signs of HIV or AIDS in the first year of life and some will die before their third birthday. However, $75 \%$ of infected children will survive up to the age of 5 years if they receive good care. Of those learners who progress to AIDS only after infancy, 30-40\% will remain in good health into their late childhood or early teens" (Louw et al; 2001:3). This means that these children are learners in our schools. In the light of the staggering HIVIAIDS figures which have been mentioned so far, it is clear that every South African will least know someone or know of someone who has this deadly disease. It will touch every citizen's life in one way or the other.

\section{Characteristics of a Successful Educator}

'The learners' feelings towards one another can be influenced considerably by the teachers' interactions with them and the attitudes she or he displays towards learners with barrier to learning. Thus if a teacher models a positive attitude towards learners with barriers to learning and development, the other learners are also more lively to interact positively with them" (Raphael \& Raphael, 1998:251). Jones and Jones (1990:64) agree when they say that one of the most important roles a teacher can play in an integrated classroom is that of a model for his or her students. It is therefore the educator who determines the class atmosphere and the mutual relationships in the classroom. The relationship between the educator and learners underlies successful teaching and learning and includes every aspect of the educator's influence on the learners.

"A significant body of research indicates that academic achievement and learner behavior are influenced by the quality of the educator-learner relationship" (Jones \& Jones, 1990:64). The teacher should treat every member of the class with equal respect and show that he or she values every learner, including the special needs child. "As classroom teachers, we need to be the supporter of our children, to be therefore them, to listen to their concerns and to understand them. No one needs this more than children with disabilities do. Their teachers must be available to explain to other educators their strengths, learning styles and goals, to tell who their friends are and to suggest strategies" (Roffey \& O'Reirdan, 1997:60-61).

According to Ryan and Cooper (1995:453) teachers who support the inclusion of learners with special educational needs have to be sensitive to their own attitudes and feeling as well as to the specific needs of the learner. They need to gain knowledge and insight on factors, which cause prejudice related to disability, and must be honest enough to recognize these in their behavior must be honest enough to recognize these in their own behavior. "Clarity about their own strengths, vulnerabilities and needs is a necessary step in preparing teachers for inclusion. Only when this has been achieved are they in a position to work as change agents who can influence the attitudes of the school community towards learners with disabilities" (Steyn, Steyn \& de Wall, 2001:139).

Engelbrecht and Green (2001:40) mention that educators play an important role in developing an inclusive learning community as they are in a direct relationship with the learners on daily basis. The educators are responsible for ensuring the safety and well-being of learners in their own classrooms. This includes field trips and after-school activities such as sport. Educators are also liable to provide proper supervision of learners at all times (Ryan \& Cooper, 1995:204). Educators should aim at creating collaborative culture, which will help educators to build on present expertise, share resources, provide moral support and create a climate of trust in which success can be challenges addressed. Educators should work together in planning, preparation and evaluation so as to learn the skills in working with other partners (Engelbrecht \& Green, 2001:35).

The South African Council of Educators (SACE) (1999:2-4) states that a successful educator should show the following conduct:

- Respect the dignity, beliefs and constitutional rights of learners, particularly the right to privacy and confidentiality of children.

- Acknowledge the uniqueness, individuality and specific needs of each learner. Guide and encourage each child to realize his potential;

- Strive to enable learners to develop a set of values consistent with those upheld in the Bill of Rights as contained in the Constitution of South Africa;

- Avoid any form of humiliation, and refrain from any physical or emotional abuse of the child;

- Use appropriate language and behavior in his or her interaction with learners, and act in such a way as to elicit respect from the learners;

- Take reasonable steps to ensure the safety of the learners

Brown, Earlam and Race (1995:46-96) claim that a successful educator: 
- Makes constructive reports rather than just a means at passing judgment;

- Encourage learners to work collaboratively rather than to compete;

- Assures learners that there is no shame or weakness involved in having emotions.

The educator should help them feel that emotions are a perfectly normal part of life.

According to Ryan and Cooper (1995:34) a successful educator demonstrates a repertoire of teaching skills that enables him/her to meet the different needs of her learners and should be familiar with theoretical knowledge and human behavior.

Van Dyk (2001:170-172) on the other hand, is more specific when he refers to the sexuality education that a successful educator should undertake:

- Make young children aware of the dangers of HIV in a very concrete manner without making them afraid, for example, by using pictures and games;

- Teach children how to keep their bodies safe and healthy and how to avoid anything that could harm the body;

- Teach children never to go home with a stranger, or walk in the street or fields with such a person, nor get into hi/her car;

- Help children to cope with death in the family;

- The fear of HIVIAIDS can be addressed by helping the young child to modify his/her absolute thinking about HIVIAIDS, such as that there is quite a lengthy period between the time that they fall ill and the time when they actually die;

- Reassure children that the "germ" that causes HIVIAIDS does not know if the people are good or bad. People with HIVIAIDS are not bad people and this disease is not a punishment for wrong doing.

The educator also needs special insight into the plight of the unaffected learners, that is, those learners who have to share resources with HIVIAIDS infected class mates. The following paragraph will deal with this issue.

\subsection{Research methodology}

The topic of this research deals with a very sensitive issue, and needs in-depth investigation on teacher's role in supporting the infected and/or affected by HIVIAIDS children in the classroom. Therefore a qualitative approach to this study was followed. "Qualitative research describes and analyses people's individual and collective social actions, beliefs, thoughts, and perceptions" (McMillan \& Schumacher, 1997:395). According to Krueger (1994:24) a researcher who intends gathering information that lays emphasis on words and observations to explain reality, should make use of the qualitative method. In this study, the data to be collected is verbal in nature. To collect data I used semi- structured interview as it helped to explain in detail. For the purpose of this paper, we interviewed and observed eight teachers from eight different schools. The interviews were held during school time and lasted approximately 2-3 minutes. I conducted individual face-to-face interviews and did the observations with all the five teachers.

The focus group as qualitative research tool was used to collect data whereby a small number of respondents discussed the role of the educator in meeting the needs of the HIV positive learner. Maykut and Morehouse (1994:71) define a group interview as a group conversation with a purpose that is a set of individual interviews that take place in a group setting. The most important quality of group interviews is using the dynamics of group interaction to gain information and insight that are less likely to be gained through individual interviews. It is conducted as open conversations in which participants may actively share ideas and ask questions or comments to questions posed by others.

\section{Findings}

\subsection{School and society}

DECS (1997:66) points out that the school should provide relevant and up to date information to all community members by using appropriate existing structures to inform and maintain awareness and relevance of HIVIAIDS education, for example, news-letters, parent groups and volunteers.

The school should encourage parental participation and involvement, conduct a needs analysis of parents and invite parents to attend curriculum committees, staff meetings and sexuality and HIVIAIDS workshops. Furthermore, the school should plan a continuous development - not a 'once-off' - by establishing parent advisory group to look at the curriculum on health and physical education issues. 
The schools should also use drama presentations on the broader theme of health issues which includes sexuality and HIVIAIDS education and involve parents and community members. Local media should be used with discretion, for example, AIDS awareness or world AIDS days.

\section{References}

Alcamo, I.E. 1993. AIDS. The Biological Basis. United States of America: Wm. C. Brown Communication, Inc.

Bartlett, J.G. \& Finkbeiner, A.K. 1998. The guide to Living with HIV Infection. United States of America. Library of Congress Cataloguingin-Publication Data.

Brown, S. Earlam, C. \& Race, P. 1995. 500 Tips for Teachers. London: British Library Cataloguing-in-Publication Data.

Clark, C. \& Easton, P. 1993. Turning the Kaleidoscope: Working with concerned about special educational needs. Rethinking special needs in mainstream schools: towards the year 2000, edited by A. Dyson \& C. Gains. London. David Fulton Publishers.

Cosgrove, J. 1991. Caring for Children and their Families in the Community. Caring for children with HIV and AIDS, edited by r. Claxton \& t. Harrison. London. Edward Arnold.

Department of education. 1996. National Education Policy Act, 1996 (Act No. 27 of 1996). Pretoria. Department of Education. National Policy on HIVIA"IDS for learners in Public Schools.

Department of Education. 1997. Education Inter University Centre for Education law and Education Policy, Understanding the South African Schools Act. Pretoria: Department of Education.

Department of Education. 2000. Education White Paper 5, 24 March 2000. Special Needs Education. Building an Inclusive Education and Training System. Pretoria: Department of Education.

Department of Education. 2001. Education white Paper 6, 30 July 2001. Special Needs Education building an Inclusive Education and Training System. Pretoria: Department of Education.

Department of Education and Children Services (DECS). 1997. Sexuality and HIVIAIDS Education. Australia: Cataloguing-in-Publication Data.

Department of Health (Salvation Army's Ethombeni Children's Home). 1998. Partnership Against AIDS. South Africa: Department of Health. South Africa.

DFID 1999. Better health for poor. International Development target Strategy Paper. London: DFID.

Duminy, P.A., Dreyer, H.J. \& Steyn, P.D.G. 1990. Education for the Student1. Cape Town: Maskew Miller Longman (Pty) Ltd.

Engelbrecht, P. \& G. Hreen, L. (eds) 2001. Promoting learner development preventing and working with barriers to learning. Goodwood, Western Cape: Van Schaik Publishers.

Gedatus, G.M. 2000. HIV and AIDS. United States of America: Capstone Press.

Gilgen, D. Campbell, C. Williams, B. Taljaard, D. \& MacPhail, C. 2000. The natural history of HIV/AIDS in South Africa. A biomedical and social survey in Carltonville. Johannesburg: Printed Matter.

Gillis, H. 1996. Counselling young people. South Africa: Kagiso Publishers.

Government Gazette, August 1999. National Policy on HIVIAIDS, for learners and educators in public schools, and students and educations in further education and training institutions. Pretoria: Government Printers.

Greenbaum, T.L. 1998. The handbook for focus Group Research. United States of America: Sage.

Haffner, D.W. 1998. Developing community support for school based AIDS Seduction. The AIDS challenge, edited by M. Quackenbush \& M. Nelson. Santa Cruz: Network Publications.

Hamacheck, D. 1995. Psychology in teaching, learning and growth. Boston: Allyn and Bacon.

Hamilton, A. 2002. An article in Fairlady magazine.

Harrison, T. \& Hall, J.M. 1991. The nursing care of children with HIV-related disease. Caring for children with HIV and AIDS, edited by R. Claxton \& T. Harrison. London: Edward Arnold.

Hoffman, M. 1996. Counseling clients with HIV disease. United States of America: Library of congress Cataloguing-in-Publication Data. Hubley, J. 1995. The AIDS handbook. $2^{\text {nd }}$ edition. London and Oxford: MacMillan.

Jefferies, G. 1988. AIDS a fact of life. Cape Town: Maskew Miller Longman (Pty) Ltd.

Jones, V.F. \& Jones, M.L.S. 1990. Comprehensive classroom management. $3^{\text {rd }}$ edition. Boston: Allyn \& Bacon.

Kapp, J.A. (Ed) 1991. Children with problems. Pretoria: Serva Publishers.

Kaufmann, T. 1995. HIV \& AIDS and older People. Great Britain: Age Concern England.

Morgan, D.L. \& Scanell, A. 1998. Planning focus groups. United States of America: Library of Congress Cataloguing-in-Publication Data. Morgan, D. 1998. The focus group guide book. United Kingdom: Library of Congress Cataloguing-in-Publication Data.

Morrow, G. 1985. Helping chronically ill children in school: A practical guide for teachers, counsellors and administrators. New York: Harper Collins.

Morton, K.L. \& Kurland, M.D. 1990. Coping with AIDS: Fact \& Fear. New York: rosen Publishing.

Mulleady, G. 1992. Counselling drug users about HIV and IADS. Great Britain: Cataloguing-in-Publication Data.

Murray, M. 1991. The role of classroom teacher. In: Porter, G.I. \& Richter, D. Changing Canadian schools. Perspective on disability and inclusion. New York: Rocher Institute.

Naierman,N. 1999. Grieving kids need guidance. [On line] http://earlychildhoodnews.com/archive/grievig.ht

NCSNET / NCESS. 1998=7. Quality Education for All. Overcoming Barriers to Learning and Development. Pretoria: Government Printer. Patton, M.Q. 1990. Qualitative Evaluation and Research Methods. $2^{\text {nd }}$ edition. Newbury Park, Ca: Sage. 
Quackenbush, M. 1988. AIDS education in school settings: Preschool- grade 3. The AIDS challenge, edited by M. Quackenbush \& M. Nelson. Santa Cruz: Network Publications.

Raphael, A. \& Raphael, R. 1998. Including learners with barriers to learning and development. Psychology for teaching and learning. What teachers need to know. Edited by N. Kruger \& H. Adams. Sandton: Heinemann Higher and Further Education.

Richter, L. \& Swart-Kruger, J. 1996. AIDS risk of South African street children: The needs for social and individual interventions. In: HIVIAIDS, children and young people in South Africa. South Africa programme.

Roffey, S. \& O'Reirdan, T. 1997. Infant classroom behaviour. London: David Fulton Publishers.

Ryan, R. \& Cooper, R. 1995. Those who can teach. 11th edition. USA: Library of Congress Cataloguing-in-Publication Data.

Sanders, P. \& Farquhar, C. 1989. Let's Talk about AIDS. Belgium Franklin Watts Ltd.

Schoub, B.D. 1999. AIDS and HIV in perspective. $2^{\text {nd }}$ edition. United Kingdom: Library of Congress.

Schurink, W. 1990. AIDS. South Africa: Human Science Research Council.

Schwarcz, S. \& Rutherford, G.W. 1988. The AIDS challenge. Edited by M. Quackenbush \& M. Nelson, Santa Cruz: network Publications. Silverstein, A. 1986. AIDS: Deadly Threat. United States of America: Library of Congress Cataloguing-in-Publication data.

Skinner, K. 1991. Social Care for Families Affected by HIV Infection: Including fostering and Adoption. Caring for children with HIV and AIDS. Edited by R. Claxton \& T. Harrison. London: Edward Arnold.

Smart, R. Dennil, K. \& Pleaner, M. 2001. A primary HIV/AIDS capacity development course for government planners. Pretoria: Department of Social Development.

Sondheimer, D. 1992. HIV infection and disease among homeless adolescents. In: Diclemente, R.J. (ed). Adolescents and AIDS: a generation of jeopardy. Newbury park, Ca: Sage.

Sontag, S. 1990. Illness as Metaphor. AIDS and its Metaphors. London: Penguin book.

South African Council of Educators (SACE). 1999. Pretoria: National Department of Education.

Starkie, J. \& Dale, R. Understanding AIDS. London British Cataloguing.

Strode, A. \& Grant, K.B. 2001. Children, HIVIAIDS and the Law. South Africa: Save the Children. (UK)

The constitution of the Republic of South Africa, 1996 (Act 108 of 1996).

UNAIDS 2001. Economic Impact of HIVIAIDS in Africa. Southern Africa AIDS Information Dissemination Service Bulletin (SAIAIDS), 9(1), March 2001.

Van Arkel, J. 1991. Living in an AIDS culture. Pretoria: University of South Africa.

Van Dyk, A. 2001. HIVIAIDS Care \& Counselling. Edited by Roger Loveday. $2^{\text {nd }}$ edition. South Africa: Hanli Venter.

Van Greunen, A. 2001. Wie gaan na die kinders kyk? De Kat, April 2001. Volume 16, No 10.

Van Niekerk, P.A. 1980. Orthopedagogiese navorsing: 'n Inleidende oriëntering. In: landman, W.A. (red), Inleiding tot die opvoedkundige navorsing praktyk. Pretoria: Butterworth.

Volberding, P.A. 1988. The AIDS epidemic. Problems in limiting its impact. The AIDS challenge, edited by M. Quackenbush \& M. Nelson. Santa Cruz: Network Publications.

Webb, D. 1997. HIV and AIDS in Africa. Southern Africa: David Phillip Publishers.

Whiteside, A. (ed) 1998. Implication of AIDS for Demography \& Policy in Southern Africa. South Africa: Creda Communications.

Whiteside, L. \& Sunter, C. 2000. AIDS the challenge for South Africa. South Africa: Tafelberg Publishers Ltd.

Wood, G.G. \& Dietrich, J.E. 1990. The AIDS epidemic: Balancing compassion and justice. Portland: Multnomah Press. 